\title{
Teacher orientation of Adiwiyata School trustees in environment character building in Malang Senior High School, Indonesia
}

Sukarsono Sukarsono

University of Muhammadiyah Malang, Indonesia.

Email: sukarsono031164@gmail.com

Lise Chamisijatin

University of Muhammadiyah Malang, Indonesia.

Email: lisechamisijatin@gmail.com

Eko Susetyorini

University of Muhammadiyah Malang, Indonesia.

Email: niniek08@gmail.com

\begin{abstract}
This research was conducted to determine the supervisory teacher orientation of Adiwiyata school program, a program of the Ministry of Environment and Ministry of Education which aims to create good conditions for schools to become places of learning and awareness of the school community so that in the future the school community can involve in taking responsibility to save the environment and sustainable development. This research is a qualitative phenomenological research carried out on the supervisory teacher of Malang Adiwiyata School program. It was shown that the highest Adiwiyata Middle School, that has ever received an award (gold) from the government as an independent school, was chosen to be Adiwiyata school as a learning location.
\end{abstract}


The data were collected by using in-depth interviews and documentation studies. Meanwhile, data analysis used triangulation techniques which were carried out simultaneously including data collection, data reduction, data presentation, verification, and drawing conclusions. The results of the study found that the Adiwiyata's supervisory teachers had a clear orientation based on activities or what was better known as a professional orientation. Orientations are arranged systematically from the most basic orientation to the peak orientation and expected to achieve as follows: policy development orientation, insight-enhancing orientation, awareness orientation, awarenessraising orientation, and conservation orientation. Conservation orientation is a direction that is created to realize the character of loving the environment. Conservation orientation in many ways illustrates that teachers and students are good conservationists. In addition, other orientations are additional orientations and are conducted outside the main orientation when it has been achieved.

Keywords: Supervisory Teacher, Orientation, Adiwiyata School

\section{Introduction}

Each Adiwiyata school has an orientation. This orientation becomes the orientation of teachers who have a particular assignment as Adiwiyata supervisor. Orientation is a person's process of knowing or understanding their surroundings and being able to place themselves in that environment. This orientation helps and directs someone in the organization to act in accordance with the environmental conditions that support them in carrying out their duties (Susetyo \& Kumara, 2012). Orientation is needed by someone in taking the actions to achieve the goals. Orientation has a function to protect and guide a person to believe that what he is doing has a strong relationship with other tasks (Stern, Deitz, \& Kalof, 1993). Susetyo \& Kumara (2012) also stated that orientation will motivate actors to take an action. Therefore, someone who acts with an orientation will have a stronger quality for the action than those who act without orientation. There are many orientations used by a person to strengthen himself and to give confidence in himself that what he is doing is something very valuable. Various orientations are created by a person so that he feels more stable in his job.

However, some orientations are stronger and held firmly by someone 
even though the workplace does not have a clear orientation and purpose (Parson, 2005). Usually, they have brought this orientation before working at that place. One of the most well-known orientations in schools is the orientation of altruism. This orientation is very popular among teachers or educators in educational institutions, especially informal education. Nevertheless, it is not infrequent for this orientation to be found in formal educational institutions (Sukarsono, 2014; Stern, Deitz, \& Kalof, 1993). An orientation that is adjusted to the orientation of the workplace, including school, will provide benefits for the schools and the teachers (Mclver, Kearns, Lyons, \& Sussman, 2009). Principals will become more skilled in setting goals and controlling teacher and student activities (Johnson, Rochkind, \& Doble, 2008); improving the teaching and learning process for both students and teachers (Leiwood, et. al, 2006); forming a unified goal accommodated by a quality orientation (Wallace Foundation, 2011).

The Adiwiyata school program is a program of Indonesia's government under the coordination of the Ministry of Environment and the Ministry of National Education. The program is implemented in accordance with the Minister of Environment Regulation No. 02/2009 on Adiwiyata Program Guidelines. The word of "Adiwiyata" consists of two words, derived from Sanskrit, namely "Adi" which means: great, noble, kind, ideal or perfect, and "Wiyata" which means a place where a person gets knowledge. norms, and ethics in social life. When combined, "Adiwiyata" indicates a good and ideal place where all knowledge, various norms and ethics can be obtained that might become a foundation for the creation of human welfare and towards the ideal of sustainable development. It represents that the Adiwiyata School was formed to create good conditions for schools to become places of learning and awareness for the school community so that in the future the school community can participate in saving the environment and sustainable development (Ministry of Environment of the Republic of Indonesia, 2010).

According to various educational researchers, schools categorize Adiwiyata as a school-based environment, green school, and so on which are very consistent in conducting environmental education activities. Environmental education according to UNESCO is a process that aims to create a world community who cares for the environment and related issues and has the knowledge, motivation as well as commitment to work both individually and collectively in finding solutions to the current environmental problems and to avoid new environmental problems (Sukarsono, 2014). 
Environmental education at present is still significantly partial, cannot anticipate problems widely, is extremely instant, and has not yet built human's character who has responsibility for the environment and the future of mankind (Roque, 2013). Many education experts criticize character education that is created since it does not have a clear form and orientation, even lack of clarity or understanding of the character of education itself. Ambiguity arises if character is expected to appear in students, especially as character preservation (conservationist in the environmental field). This situation raises public's distrust of the process and results of character education carried out by the government through various educational institutions (Sukarsono, 2014).

Environmental education implemented by the Ministry of Education and Culture in collaboration with the Ministry of Environment on the Adiwiyata program seeks to integrate approaches to school's environmental management through planning till implementing a conservation-oriented learning environment. This program has been going on for a long time, so several schools have received awards three times in a row for the Adiwiyata Mandiri Award. Schools that have obtained the Adiwiyata Mandiri award provide instructions on what, why, and how the principal and teachers in the school have knowledge and values of nature or the environment, which will then be shared and internalized with the students (Mubarak, 2006).

Teachers and school principals are the main actors in character education for students in schools. However, in reality, teachers and school principals are frequently the same as a manner or an integral part of the national education process and become important targets to be achieved from an educational process (Ministry of Education's Character Education Team, Sarjono, 2004). A character as a human being who cares about the environment is still rare or difficult to find in educational institutions in the world. The development of values for environmental stewardship is still disintegrated and only carried out by those with an interest or NGOs that operate with very limited, unstructured and even unsustainable manners (Emeakaroha, Ang, \& Yan, 2012).

A character must be created with knowledge and values. There are several theories and models proving that human behavior can damage or vice versa to the environment. One of the models used in this study is the model proposed by Fietkau \& Kessel (1981) and the opinion of Evans, et.al (2006) which states that the behavior of a person or group of people to stand for the environment depends on their knowledge, attitudes and values as well as supporting factors -such as economic factors- that enable them to carry out 
environmental conservation activities. Furthermore, character education is not new in Indonesian national education system.

Currently, at least two subjects are given to foster the character and behavior of good students, namely Religious Education and Citizenship Education. However, a character development through these two subjects has not yielded satisfactory results because of several reasons. First, the two courses tend to provide new knowledge about values through the subject materials. Second, learning activities in these two subjects generally do not encourage the internalization of the values possessed by each student so that the students behave toughly. Third, two subjects are not enough to form the student's character. Student's character development needs to involve more subjects, even all subjects. In addition, the student's development activities and day-today school management must also be designed and implemented to support character education. School as one of the character building institutions for students has a duty to build the character set by the government. One of the characters that must be raised in students is the "character of loving the environment".

\section{Methods}

The approach of this research is a qualitative approach with phenomenology with existing models (Winarno, 2007). A qualitative approach is used because the data is soft collected data, with an emphasis on descriptions of people, places and conversations and does not apply statistical procedures. The phenomenological approach chosen for this study seeks to enter into the world of conceptual subjects to gain a deeper understanding of how and what subjects are structured around the events of daily life. Thus, this type of research is non-experimental. A qualitative phenomenology is an approach that emphasizes natural conditions, field work, while the main instrument is the researcher himself and more descriptive disclosures.

The focus of this research is visible phenomena and underlying symptoms based on the subjective understanding of the researcher himself (Lincoln \& Guba, 1985). This research was conducted at the research location for eight months, from November 2014 to July 2015. The research was held in two schools representing all schools that have received recognition as Adiwiyata Schools. The two schools were selected as samples since those schools have existed as Adiwiyata Mandiri schools and received the Adiwiyata award four times in a 
row, and the fifth award is obtained because the school has been able to carry out the program activities. Data collection uses three techniques, namely indepth interviews, participant observation, and documentation study (Lincoln \& Guba, 1985; Moleong, 2005). Meanwhile, the value data were collected using in-depth interviews with the procedure carried out by Kempton et al (1995); and Hanada, et al (Dietz, Fitzgerald, \& Shwom, 2005).

The degree of validity is in the following ways: expanding engagement in the field, observing diligently, triangulating (methods and data sources). The fulfillment of dependency criteria carried out according to Lincoln \& Guba (1983) guidelines include; data presentation and data analysis results, data reconstruction and synthesis results: covering the structure of the theme categories, definitions and relationships; findings and conclusions; and the final report and relationship with the latest literature, integration, and interpretation of the relationship concepts. The certainty of the criteria is carried out through a Focus Group Committee (Moleong, 2002). After collecting data, the researcher will reduce data, present data, draw tentative conclusions, and verify. During the data reduction process, the material that has been collected will be analyzed, compiled systematically, and highlighted the main points of the problem. Analysis of activity data is based on the theory of Miles \& Huberman (Linacre, 1995) which consists of data reduction, data presentation, and drawing conclusions or data verification.

\section{Results and Discussion}

All this time, both Adiwiyata and non-Adiwiyata schools are considered not to have a clear orientation in building the student's character to become environmentalists. The results showed that the teachers at Malang Adiwiyata School already had a clear orientation in building character so that students became keen on the environment. This breaks the assumption that so far schools have not had a clear orientation in shaping the students' character who love the environment.

\section{Forms of Teacher Orientation in Adiwiyata School Program}

Orientation created by Adiwiyata School supervisory teachers can be categorized as an action orientation. Referring to the action orientation proposed by Talcott Parson, the human action orientation is determined by two orientations, called motivational orientation and value orientation (Parsons, 2005), the results of this study indicate that school as a closed system has 
two forms, namely orientation. The motivation orientation grows in school principals and teachers because they want their school to excel as an Adiwiyata School and receive awards from the government at both the regional and central levels. Meanwhile for the teacher's value orientation, it is because the Adiwiyata School Supervisor already has noble values as an environmentalist even before the Adiwiyata School program exists. The value orientation that the supervisory teachers have refers to normative standards and these thoughts can influence the life pattern and students at school. The values that are created come from the Adiwiyata activity guidelines set by the government.

However, these values had previously existed in the supervisory teacher itself even before the Adiwiyata program was introduced by the government. Theses are generally expressed by the supervisory teacher as 'a pleasure' or 'an interest' in environmental issues. According to him, in the absence of pleasure or interest in environmental issues, it would not be easy for someone to become a supervisory teacher for the Adiwiyata program. The interest that is assessed on environmental problems has led a teacher to do strenuous activities beyond the responsibility that must be carried out as a teacher. This teacher's behavior is similar to the altruistic behavior proposed by Stern, Deitz, \& Kalof (1993). The results of this study indicate that before teachers supervise Adiwiyata program with idea of orientation, they have great motivation as altruists with the orientation suggested by Stern, Deitz, \& Kalof (1993) and Sukarsono (2014).

Stern, Deitz, \& Kalof (1993) argues that a person's motivation in the activities of his own environmental development is based on egotistical orientation, social orientation, and biosphere orientation. The results show that before becoming Adiwiyata program supervisory teachers, they must have values that are cumulatively expressed by them as 'enjoyment' or 'interest' towards environmental problems. This finding also supports the suggestion of Sukarsono (2014) which states that a person's motivation to act in the field of environmental concern, not only based on orientation as suggested by Stern, Deitz, \& Kalof (1993), but also on religious orientation. Religious orientation is not only found in religious schools but also in public schools. The teacher, a supervisor of Adiwiyata, stated that his actions would suffer if he was only oriented to worldly things so that the orientation of his actions must also be based on the orientation of life after death. With altruistic behavior, Adiwiyata teachers receive an education or a training from the Ministry of Environment and the Ministry of Education of the Republic of Indonesia. Based on the results of the training, all Adiwiyata programs are designed and implemented. 
The orientation created by the supervisory teacher of Adiwiyata School consisted of several structured orientations that were systematic and sequential from the most basic orientation to the final orientation. The order of orientation carried out by the teacher is as follows: 1) Orientation of school policy development; 2 ) orientation to increase insight; 3 ) orientation to increase awareness and attention; and 4) orientation of conversation. Conservation orientation is the orientation of the entire school family where all school activities must reflect conservation activities. If the summit orientation has been completed, the supervisory teacher must develop a further orientation, namely a development Orientation.

\section{The Policy Development Orientation}

School has determined the school's vision, mission, goals, strategy and program policies. For schools that have not implemented the Adiwiyata program, this policy has not included the environment as a central issue in all school activities, especially in teaching and learning activities. Meanwhile, in Adiwiyata school, the whole school policy must make the environment as a central issue in all school activities, including in the teaching and learning process. Policy is essentia; because it relates to the existence of the principal as the controller of all activities in the school. The principal must know how to focus on school activities that will be implemented through the designed vision and mission and how the goals will be achieved through mutual agreement (Mclver, et. al, 2009); the principal has become a school- transforming mission to create a culture for students to learn (Johnson Rochkind, \& Doble, 2008); enhance the learning process with motivation and commitment (Leithwood, 2006); and form a vision of success for students with high standards, to create a good educational climate, and build togetherness and the ability of teachers to excel (Wallace Foundation, 2011).

\section{The Insight-Enhancing Orientation}

Insight-enhancing orientation is carried out if the policies to support the implementation of the Adiwiyata School program have been agreed upon and approved by the school principal. This orientation is needed so that teacher's competence in the field of science and skills in Adiwiyata activities can increase. The Increase of insight is truly required, especially by teachers who will carry out the teaching and learning process, and develop the students' character to love the environment. This Orientation can be applied through various activities such as training, seminar, workshop, visiting various locations both educational 
institutions and other institutions. Various activities to gain more insight are carried out on teachers in the form of theory and practice. Enhacing insight is fulfilled to increase the critical awareness of students and teachers. Critical awareness will distinguish a person from others in the quality of the actions (Murwani, 2006). Insight or knowledge is an absolute component that must be possessed to build awareness, values, attitudes and behavior of the community (Parson, 2005; Sukarsono, 2014). Such behavior is called volitional behavior because it has a clear orientation and is based on deep knowledge and thought.

\section{The Awareness-Raising and Caring Orientation}

Raising awareness during the early stages of the school component orientation must be achieved before moving to the next activity. This orientation is based on the consideration that all activities in the school environment will not be running well unless they are based on a strong awareness of students, teachers, school principals, administrative staff, park rangers, and school canteen managers. The program of Adiwiyata supervisory teacher hopes that the ultimate goal of environmental education will change the behavior based on a strong awareness of what to do.

Awareness-raising activities are carried out in various ways, including visiting various locations that carry out activities related to environmental conservation and management (landfill, electric dams, flood and landslide locations, etc.). This activity was deemed necessary as teachers would be the main part of the entire program and lead the Adiwiyata School. The result of teacher's awareness-raising must be followed by determining the role of each teacher as the person in charge of the Adiwiyata program that supports the school environment. The determination of this responsibility is adjusted to the interests and abilities possessed by each teacher. Some areas that must be the responsibility of teachers include waste, water, school's gardens, food in the canteen, energy, and others.

The forms of self-awareness of students, teachers, school principals, and other school supporters must be able to form behaviors that support environmental protection and sustainable use of natural resources. This concern must arise in the entire school family as a continuation of the awareness awakening of the school community. These forms of concern must be seen in behaviors that are no longer enforced, but arise naturally, although in many cases they still have to go through the guidance of a teacher or school principal. Building awareness is not only performed within the school environment but also 
outside the school through various activities. For example, students participate in cleaning and waste management activities in the village community around the school and help to organize the environment in and around the wells to prevent contamination by either solid waste or liquid waste.

Increasing awareness and attention is an entry point for teachers to prepare future activities so that they are more successful in forming the leadership skill (Komives, et. al, 2006); is a major and very important component that must be possessed by someone in action, and critical awareness of students and the school community must be built by looking more at aspects of systems and structures as sources of problems (Murwani, 2006); including the problems of globalization (Crawford \& Kirby, 2008). The form of awareness activities at the initial stage was implemented to all teachers in schools through mentoring. Murwani (2006) states that the role of the teacher is more appropriate to develop critical awareness as a facilitator and students as subjects, not learning objects. Building awareness and concern for students should not only be done in the school environment without understanding the conditions and culture that exist in society where the students live everyday (Brown, 2006).

\section{The Environmental Conservation Orientation}

A behavior of preserving natural resources and the environment in the entire school family is a behavior that becomes the peak orientation in schools which implement the Adiwiyata program. Conservation behavior determines the success of the program, considering that the result of awareness and concern is the existence of conservation behavior itself. Even Baca-Motes, et. al (2013) states that it is an indicator of a person's commitment. Sengupta, Das, \& Maji (2010) explains that the term of "environmental care" has a very large meaning, not only being aware, caring, having good values and attitudes towards the environment, but also behavior and ability to solve various environmental problems. Thomson, Hoffman, \& Staniforth (2003) stated that conservation behavior is the best way to evaluate the success of environmental education.

Conservation behavior in each school will have different forms according to the abilities, knowledge, experience, and capabilities of supporting resources. However, the conservation activities consist of two main points, namely environmental protection and sustainable use of natural resources. Various conservation behaviors that are generally carried out in these schools are; energy conservation, minimization and utilization of waste, air protection, protection of healthy food, and others. All of these activities must become a part of teaching 
and learning activities especially in the theory, direct observation as well as practice in the field. The efforts to create conservation behavior can be done in various ways, including through social marketing and educational methods (Monroe, 2003); Scientific and contextual learning approaches are applied (Machin, 2014; Puspandari, 2012); or practices of solid waste management (2010); even using community engagement to monitor the use of energy by using smartphone technology (Emeakaroha, Ang, \& Yan, 2013).

The results of Sukarsono's (2014) research state that in a religious education institution that intensively carries out environmental education activities, at least there is a character that awakens in himself as a student when he continues to do intensive education about the environment. This character is called the character of conservation or conservationist which is taken from the English word of "conservationist". Character is formed relatively and differently for each person, but basically, these findings show that a person's character is awakened by the various kinds of knowledge and values that they have.

\section{The Program Development Orientation}

An additional orientation for supervisory teachers of Adiwiyata school is that their school has received the Adiwiyata Mandiri Award. Each school that has succeeded in obtaining an award for Adiwiyata Mandiri is required to build another school that has not yet received the award or will be proposed as an Adiwiyata school. Greenlee (2007) states that the development orientation of various structural matters must be carried out by the government. However, for the Adiwiyata School program, the development program is carried out as the request of the government, while the internal program development is carried out as the initiative of the supervisory teachers or the school itself.

The development orientation is conducted by the supervisory teachers as a personal and institutional responsibility to maintain the school's status as a champion of Adiwiyata Mandiri. Even though this orientation is mandatory, in reality, the supervisory teachers of Adiwiyata Mandiri have carried out training activities to other schools independently or were requested by the school. Thus, the obligation imposed by the government has been carried out in advance by them and it has become a personal orientation which is inherent in the teacher.

The development orientation in learning activities should be an orientation that is owned by every teacher or school management (Bolman $\&$ Deal, 1994). The development orientation is carried out because of future demands that are not only needed by the supervisory teachers to help other 
schools but also to help themselves to develop their knowledge and experience. The development orientation will be introduced to teachers about the broader life (Pillay, 2012), then it will provide benefits between teachers and institutions who make cooperation and even benefits for students, either directly or indirectly.

\section{Conclusions}

From the discussion above, it can be concluded that the existence of orientation in character education activities is an important thing that must be owned by a teacher. Likewise in educating students with environmental characteristics and systematic orientation. The orientation that the supervisory teachers must have consists of: policy development, knowledge enhancement, awareness-raising, and conservation. Development orientation can be carried out if the conservation orientation has been successfully implemented. The implication of these results is that character education activities in schools to build the character of students who love the environment can be done by building the first orientation. Teachers and schools can arrange an orientation to build students' character and a school-based environment by imitating the steps taken by the supervisory teachers of Adiwiyata school as revealed in this study.

\section{References}

Baca-Motes, K., Brown, A., Gneezy, A., Keenan, E. A., \& Nelson, L. D. (2013). Commitment and behavior change: Evidence from the field. Journal of Consumer Research, 39(5), 1070-1084. https://doi.org/10.1086/667226

Bolman, L., \& Deal, T. (1994). Becoming a teacher leader: From isolation to collaboration. Corwin Press.

Brown, P. S. (2006). The value of enhancing students' critical awareness of discourse. Paper of Centre for English Language Studies, Department of English, University of Birmingham, United Kingdom.

Crawford, E. O., \& Kirby, M. M. (2008). Fostering students' global awareness: Technology applications in social studies teaching and learning. Journal of Curriculum and Instruction, 2(1), 56-73. https://doi.org/10.3776/ joci.2008.v2n1p56-73. 
Dietz, T., Fitzgerald, A., \& Shwom, R. (2005). Environmental values. Annu. Rev. Environ. Resour., 30, 335-372.

Emeakaroha, A., Ang, C. S., \& Yan, Y. (2012). Challenges in improving energy efficiency in a university campus through the application of persuasive technology and smart sensors. Challenges, 3(2), 290-318. doi:10.3390/ challe3020290.

Evans, K., de Jong, W., Cronkleton, P., Sheil, D., Lynam, T., Kusumanto, T., \& Colfer, C. J. P. (2006). Guide to participatory tools for forest communities. CIFOR.

Fietkau, H. J., \& Kessel, H. (1981). Environmental education. Umweltlernen. Veraenderungsmoeglichkeiten des Umweltbewusstseins.

Greenlee, B. J. (2007). Building teacher leadership capacity through educational leadership programs. Journal of Research for Educational leaders, 4(1), 44-74.

Huberman, M., \& Miles, M. B. (1992). Analisis data kualitatif. Penerbit Universitas Indonesia.

Johnson, J., Rochkind, J., \& Doble, J. (2008). A mission of the heart: Leaders in high-needs districts talk about what it takes to transform a school. Public Agenda.

Kempton, W., Boster, J. S., \& Hartley, J. A. (1996). Environmental values in American culture. MIT Press.

Khasanah, F. U. (2012). Membangun kesadaran remaja berperilaku sehat. Makalah BKKBN Pusat.

Komives, S. R., Longerbeam, S. D., Owen, J. E., Mainella, F. C., \& Osteen, L. (2006). A leadership identity development model: Applications from a grounded theory. Journal of College Student Development, 47(4), 401-418. doi: $10.1353 / \operatorname{csd}$.2006.0048

Leithwood, K., Day, C., Sammons, P., Harris, A., \& Hopkins, D. (2006). Seven strong claims about successful school leadership. NCSL/DfES.

Linacre, J. M. (1995). Learning from qualitative data analysis; http://www.rasch. org/rmt/ rmt91a.htm. Access, 28 February 2011.

Lincon, Y. S., \& Guba, E. G. (1985). Naturalistic inquiry. Sage.

Machin, A. (2014). Implementasi pendekatan saintifik, penanaman karakter dan konservasi pada pembelajaran materi pertumbuhan. Jurnal Pendidikan IPA Indonesia, 3(1). 28-35. https://doi.org/10.15294/jpii.v3i1.2898 
McIver, M. C., Kearns, J., Lyons, C., \& Sussman, M. (2009). Leadership: A McREL report prepared for Stupski Foundation's Learning System. Midcontinent Research for Education and Learning (McREL).

Mohamed, N. (2012). Revitalising an eco-justice ethic of Islam by way of environmental education: Implications for Islamic education (Doctoral dissertation, Stellenbosch: Stellenbosch University).

Moleong, L. J. (2005). Metodologi penelitian kualitatif. Remaja Rosda Karya.

Monroe, M. C. (2003). Two avenues for encouraging conservation behaviors. Human Ecology Review, 10 (2). 113-125.

Mubarak, Z. M. (2006). Pendidikan karakter. Alfabeta.

Murwani, E. D. (2006). Peran guru dalam membangun kesadaran kritis siswa. Jurnal Pendidikan Penabur, 6(5), 59-68.

Parson, T. (2007). Classical sociological theory $2^{\text {nd }}$ ed. Blackwell Publishing.

Pillay, J. (2012). Keystone Life Orientation (LO) teachers: Implications for educational, social, and cultural contexts. South African Journal of Education, 32(2), 167-177. doi: 10.15700/saje.v32n2a497

Puspandari, D. (2012). Upaya meningkatkan kesadaran pelestarian lingkungan hidup melalui pembelajaran PKLH berbasis CTL. Makalah SMP Negeri 1, Balikpapan.

Roque, M. À. (2013). Towards cologised thought. Interview with Edgar Morin. Retrived from http://www.iemed.org/observatori/arees-danalisi/ arxius-adjunts/qm-16-originals/roquema_towards $\% 20$ cologised $\% 20$ thought\%20interview\%20with\%20edgar\%20morin_qm16.pdf

Sengupta, M., Das, J., \& Maji, P. K. (2010). Environmental awareness and environment related behaviour of twelfth grade students in Kolkata: Effects of stream and gender. Anwesa, 5(1), 1-8.

Smyth, D. P., Fredeen, A. L., \& Booth, A. L. (2010). Reducing solid waste in higher education: The first step towards 'greening'a university campus. Resources, Conservation and Recycling, 54(11), 1007-1016. https:// doi.org/10.1016/j.resconrec.2010.02.008

Stern, P. C., Dietz, T., \& Kalof, L. (1993). Value orientations, gender, and environmental concern. Environment and Behavior, 25(5), 322-348. https://doi.org/10.1177/0013916593255002

Sukarsono, (2014). Model pendidikan konservasi keanekaragaman hayati hutan rakyat di Pesantren Annuqayah Sumenep. Disertasi tidak diterbitkan. 
Teacher orientation of Adiwiyata School ... (Sukarsono Sukarsono, Lise Chamisijatin, and Eko Susetyorini)

Pascasarjana Universitas Negeri Malang.

Susetyo, Y. F., \& Kumara, A. (2012). Orientasi tujuan, atribusi penyebab, dan belajar berdasar regulasi diri. Jurnal Psikologi, 39(1), 95-111. doi: 10.22146/ jpsi.6969

Thomson, G., Hoffman, J., \& Staniforth, S. (2003). Measuring the success of environmental education programs. Canadian Parks and Wilderness Society and Sierra Club of Canada.

Torkar, G., Zimmermann, B., \& Willebrand, T. (2011). Qualitative interviews in human dimensions studies about nature conservation. Varstvo Narave, 25. 39-52.

Wallace Foundation. (2011). The school principal as leader: Guiding schools to better teaching and learning. Retrieved from http://www. wallacefoundation.org/knowledge-center/school-leadership/effectiveprincipal- leadership/Documents/The-School-Principal-as-LeaderGuiding-Schools-to-Better-Teaching-and-Learning.pdf.

Winarno, A. (2007). Internalisasi nilai-nilai kewirausahaan; Pendekatan fenomenologis pada SMK Negeri 3 Malang. Disertasi tidak diterbitkan. Program Pascasarjana Universitas Negeri Malang. 
Journal of Social Studies (JSS), Volume 17, Number 1, 2021: 21-36 